Vol. 2 No. 2 Juli 2020

\title{
HUKUM WARIS ISLAM DALAM PELAKSANAAN DAN PANDANGAN MASYARAKAT ENGGANO BENGKULU
}

\author{
Ahmad Dasan, Mikho Ardinata \\ Fakultas Hukum Universitas Muhammadiyah Bengkulu \\ Jl. Adam Malik, Gading Cempaka, Kota Bengkulu \\ ahmaddasan@umb.ac.id,mikhoardinata@gmail.com \\ Naskah dikirim : 29 Maret 2020 \\ Naskah diterima untuk diterbitkan : 7 Juni 2020
}

\begin{abstract}
Abstrak
Kekerabatan suku bangsa masyarakat pulau Enggano dipertimbangkan melalui keturunan ibu (matrilineal). Sistem kekerabatan matrilineal merupakan sistem kekerabatan yang anggotaanggotanya menarik garis keturunan hanya dari pihak ibu saja terus menerus ke atas karena faktor historis etnik Enggano dahulu sering berperang antar suku dan seringnya kaum lelaki yang merantau meninggalkan kampung halaman, sehingga agar harta tidak hilang dan tetap terjaga harta waris dilimpahkan kepada anak perempuan tertua.

Hukum Waris Islam di dalam Masyarakat Enggano dipahami secara subtanntif, bahwa terdapat nilai-nilai dalam agama Islam yang sudah diadopsi dan mewarnai sistem hukum adat yang mereka terapkan dimasyarakat selama ini. Ada kecenderungan keengganan masyarakat menerapkan hukum waris Islam karena menganggap bahwa hukum waris Islam terlalu banyak aturan yang pada akhirnya menjauhkan dari rasa keadilan dalam proses pembagian waris. Keadilan yang dipahami oleh masyarakat adalah keadilan yang mendasarkan atas keadilan dalam perspektif hukum adat; Masyarakat Bengkulu menempatkan hukum waris Islam dalam berbagai dimensi, berdasarkan pemahamannya terhadap pewarisan yang sebatas menggunakan prinsip keadilan menurut perspektif adat. Oleh karena itu, hukum waris Islam ditempatkan dalam dua dimensi, yaitu: pertama, menempatkan hukum waris Islam sebagai sebuah tata aturan yang berisi nilai-nilai agama, yang bagi masyarakat Enggano nilai-nilai tersebut sudah diterapkan dalam hukum waris adatnya. Kedua, hukum waris Islam ditempatkan seperti halnya hukum adat. Pemahaman masyarakat Enggano bahwa apa yang diyakini sebagai hukum waris adat yang sudah mengadopsi hukum waris Islam pada akhirnya menempatkan pemahamanya pada dimensi yang ambigu. Satu sisi mereka menganggap bahwa hukum waris yang diterapkanya sebagai sebuah tata aturan yang sudah relavan dan tidak bertentangan dengan hukum waris Islam. Sementara disisi yang lain, implementasi dari hukum waris adat tersebut masih jauh dari prinsip dasar hukum waris Islam. Dalam perspektif teori konstruksi sosial, bahwa pemahaman dan pelaksanaan masyarakat Enggano terhadap hukum waris Islam merupakan bentuk dari kristalisasi nilai-nilai yang mereka yakini sebagai sebuah tata aturan yang merupakan konstruksi dari kebiasaan dan adat budaya masyarakat Rejang dan Serawai. Sehingga pada akhirnya konstruksi ini merupakan perpaduan antara nilainilai lama yang sudah ada (adat) dengan nilai-nilai agama yang dianutnya (nilai Islam). Meskipun nilai baru yang lahir bukan merupakan bentuk asimilasi, tetapi bentuk dari akulturasi.

Kata Kunci : Hukum Waris Islam, Pelaksanaan dan Pandangan Masyarakat Enggano
\end{abstract}

\section{Pendahuluan}

Masyarakat Engganodi Provinsi Bengkulu Merupakan salah satu suku yang paling terisolir secara geografiskarena terpisah dari Bengkulu daratan dan berada di pulau sebndiri dan mayoritas memeluk agama Islam, Berkaitan dengan pembagian waris sebagian mereka beranggapan bahwa untuk urusan pembagian waris berdasarkan adat budaya yang selama ini mereka anut dan mereka sepakati,. Ini sebuah fenemomena menarik, sebab disatu sisi mereka merasa perlu akan 
Vol. 2 No. 2 Juli 2020

sebuah aturan yang mengatur bagaimana sebenarnya warisan itu dibagi, disisi lain, aturan hukum waris yang selama ini dianutnya merupakan hasil dari turun temurun.

Fenomena lainya adalah dengan kebijakan pemerintah daerah yang menghidupkan dan memfasilitasi kembali keberadaan Badan Musyawarah Adat (BMA). BMA diharapkan mampu melestarikan budaya dan kearifan lokal yang menjadi ciri khas etnisitas masyarakat Bengkulu. ${ }^{1}$ Namun demikian, ternyata keberadaan BMA tidak hanya sebatas sebagai garda terdepan melestarikan kearifan lokal etnisitas Bengkulu, tetapi juga sudah menjadi figur dan tokoh panutan masyarakat. Sehingga semua persoalan yang terjadi di masyarakat, semua melibatkan BMA untuk menyelesaikannya, padahal mereka ini adalah pimpinan informal, meski secara politik keberadaannya dilegalkan oleh kebijakan pemerintah daerah. Tidak terkecuali persoalan pembagian warisan, posisi BMA juga menjadi cukup penting untuk dilibatkan dalam proses pembagian warisan kelompok etniknya. Pergeseran ini menjadi berbahaya, sebab nilai-nilai agama yang sebenarnya sudah mengatur tentang hukum waris seakan sudah bergeser dan tergantikan kekuatan adat budaya. Fenomena ini menarik untuk dilakukan pendalaman tentang problematika ini melalui penelitian, sehingga diperoleh argumentasi yang kuat untuk menjawab persoalan ini.

A. Rumusan Masalah

Berdasarkan latar belakang penelitian di atas kemudian dirumuskan masalah penelitian, "Bagaimana Pandangan dan pelaksanaan Masyarakat Bengkulu terhadap Hukum Waris Islam”. Untuk menjawab rumusan masalah tersebut, kemudian disusun pertanyaan-pertanyan penelitian sebagai berikut:

1. Bagaimana pandangan masyarakat Enggano terhadap hukum waris Islam?.

2. Seberapa jauh masyarakat Enggano menempatkan hukum waris Islam dalam pelaksanaan pembagian waris?.

\section{B. Kerangka Teori}

\section{Teori Kesadaran Hukum}

Ide tentang kesadaran warga-warga masyarakat sebagai dasar sahnya hukum positif tertulis, ditemukan dalam ajaran-ajaran Rechtsgefuhl atau Rechtsbewustzijn yang intinya adalah, bahwa tidak ada hukum yang mengikat warga-warga masyarakat kecuali atas dasar kesadaran hukumnya. ${ }^{2}$

Di Indonesia masalah kesadaran hukum mendapat tempat yang sangat penting di dalam politik hukum khususnya, serta pembangunan pada umumnya yang merupakan suatu perubahan yang direncanakan. Kesadaran hukum dianggap sebagai variabel bebas, sedangkan taraf ketaatan merupakan variabel tergantung. ${ }^{3}$ Selain itu kesadaran hukum dapat merupakan variabel bebas yang terletak antara

\footnotetext{
${ }^{1}$ Wawancara dengan Bapak Drs. S. Effendi, MS, Ketua BMA ( Badan Musyawarah Adat) Provinsi Bengkulu, Pemda Bengkulu 4 Januari 2015.

${ }^{2}$ Soerjono Soekanto dan Soleman B. Taneko, Hukum Adat Indonesia (Jakarta: Rajawali Press, 1983), hlm. 338.

${ }^{3}$ Soerjono Soekanto dan Mustafa Abdullah, Sosiologi Hukum dalam Masyarakat (Jakarta : Rajawali Press, 1982), hlm. 208.
} 
Vol. 2 No. 2 Juli 2020

hukum dengan perilaku manusia yang nyata. Perilaku yang nyata terwujud dalam ketaatan hukum, namun hal itu tidak dengan sendirinya hukum mendapat dukungan sosial, dukungan sosial hanya diperoleh apabila ketaatan hukum tersebut didasarkan kepada kepuasan, oleh karena kepuasan merupakan hasil pencapaian hasrat akan keadilan. Dari uraian di atas dapat disimpulkan bahwa masalah kesadaran hukum di Indonesia perlu dikaji sercara mendalam dengan maksud untuk dapat menjelaskan aspek-aspek yang terkait dengannya. ${ }^{4}$

Kesadaran hukum berkaitan dengan nilai-nilai yang tumbuh dan berkembang dalam suatu masyarakat. Dengan demikian masyarakat mentaati hukum bukan karena paksaan, melainkan karena hukum itu sesuai dengan nilainilai yang ada dalam masyarakat itu sendiri.

Eugen Ehrlich, menganjurkan terdapatnya keseimbangan antara keinginan untuk mengadakan pembaharuan hukum melalui perundang-undangan dengan kesadaran untuk memperhatikan kenyataan-kenyataan yang hidup dalam masyarakat. Kenyataan-kenyataan tersebut ia namakan living law dan just law, dan itu merupakan kunci bagi teorinya. Lebih lanjut Ehrlich mengemukakan bahwa :

"Hukum positif yang baik dan efektif adalah hukum yang sesuai dengan "living law" atau disebut "inner order" darimasyarakat yang mencerminkan nilainilai kehidupan di dalamnya.",

Dari pengertian ini dapat disimpulkan bahwa hukum itu tidak saja sebagai gejala normatif akan tetapi juga merupakan suatu gejala sosial. ${ }^{6}$

Tentang fungsi hukum sebagai sarana pembaharuan masyarakat, dikemukakan suatu konsepsi ilmu hukum yang mirip atau bersumber dari teori Roscoe Pound sebagai pemuka utama mazhab Sosiological Jurisprudence dan Pragmatic Legal Realism di Amerika Serikat. Teorinya dikenal sebagai "Law as a tool of social engineering", dikembangkan oleh Mochtar di Indonesia dalam jangkauan dan ruang lingkup yang lebih luas.

\section{Teori asy-Syathibi (Maqâsid asy-Syari'ah)}

Seringkali dinyatakan bahwa mashlahah sebagai prinsip penalaran hukum secara luas, menyatakan bahwa "kebaikan" adalah "halal" dan bahwa halal mestilah baik. Jauh sebelum Syatibi mengusung konsep Mashlahah-nya, pada awal abad kedua belas Ghazali dalam karyanya al-Mustafa mendefinisakan mashlahah sebagai ungkapan untuk mencari sesuatu yang bermanfaat atau untuk menghilangkan sesuatu yang merugikan (madharah) untuk memelihara agama, memelihara kehidupan, memelihara akal, memelihara keturunan dan memelihara harta benda. Menurut Ghazali, Mashlahah sendiri terbagi menjadi tiga kategori. Pertama, jenis Mashlahahyang memiliki bukti tekstual yang mendukung pertimbangannya. Kedua, adalah jenis Mashlahah yang diingkari oleh bukti tekstual.Jenis ketiga adalah Mashlahah yang tidak didukung ataupun disangkal oleh bukti tekstual.Untuk kategori ketiga tersebut perlu diperiksa lebih jauh dari

\footnotetext{
${ }^{4}$ H.R. Otje Salman, KesadaranMasyarakat terhadap Hukum Waris, hlm, 39

${ }^{5}$ Mochtar Kusumaatmadja, Hukum, Masyarakat dan Pembinaan Hukum Nasional, (Bandung : LPHK Fakultas Hukum Unpad-Bina Cipta, 1976), hm. 5.

${ }^{6}$ H.R. Otje Salman, Kesadaran Masyarakat terhadap Hukum Waris, hlm, 37.
} 
Vol. 2 No. 2 Juli 2020

segi kekuatannya. Dari segi ini ada tiga tingkatan Mashlahah: yaitu daruriyat, alhajiyat dan tahsiniyat.

Selaras dengan konsep Mashlahah Ghazali.Syatibi mendefinisikan Mashlahah adalah apa-apa yang menyangkut rizki manusia, pemenuhan penghidupan manusia, dan pemerolehan apa-apa yang dituntut oleh kualitaskualitas emosional dan intelektualnya, dalam pengertian yang mutlak.

Sebagaimana Ghazali, Syatibi membagi maqasid atau mashâlih menjadi tiga, yang bersifat dhārurị (harus), haji (diperlukan) dan tahsini (dipujikan). Maqāshid dhäruri dikatakan harus karena mutlak diperlukan dalam memelihara mashalih din (agama dan akhirat) dan dunya (dunia).Sedangkan mashalih hajiyat dibutuhkan untuk memperluas tujuan maqashid dan menghilangkan keketatan makna harfiah yang penerapannya membawa kepada rintangan dan kesulitan dan akhirnya kerusakan maqasid as-Syariah.Lalu tahsiniyat berarti mengambil apa yang sesuai dengan kebiasaan ('adat) yang paling baik dan menghindari cara-cara yang tidak disukai oleh orang-orang yang bijak.

\section{Teori Taufik Abdullah}

Potret sejarah legislasi hukum Islam di Indonesia sebenarnya dapat dibaca mulai dari proses masuknya Islam di Negeri ini. Secara sosiologis dan kultural hukum Islam telah menyatu dan menjadi hukum yang hidup.Akulturasinya dengan adat terkadang melahirkan sikap yang ekstrim karena kecintaan terhadap Islam. Di beberapa daerah seperti Aceh, Sulawesi Selatan, Minangkabau dan Riau, hukum Islam diterima tanpa reserve, sederajat dengan hukum adat setempat. Hal ini dapat dibuktikan dengan adanya pepatah yang mengatakan adat bersendi syara', syara' bersendi kitabullah, dan syara mengata adat memakai, yang keduanya merefleksikan bagaimana kental dan menyatunya hubungan antara hukum Islam dengan adat Minangkabau.

Telah banyak karya para penulis yang menyangkal teori Snouck Hurgronje termasuk Taufik Abdullah yang menjadi salah satu pelopor penentang teori Hurgronje yang menyimpulkan bahwa antara adat dan Islam di Minangkabau tidak ada pertentangan, Islam melengkapi adat dan adat melebur dengan Hukum Islam. Hamka mengibaratkan Perpaduan Islam dan adat itu diibaratkan bagaikan percampuran dari air dan minyak dalam susu ${ }^{7}$ sehingga antara dua konsep yang berbeda bahkan sering dianggap bertentangan terbukti dapat melebur dan berpadu jadi satu dan menciptkan sebuah hubungan yang saling melengkapi. Nasrun berpendapat, Islam adalah kesempurnaan adat, tidak hanya dalam aspek supranatural, tetapi juga dalam perumusan adat itu sendiri. ${ }^{8}$

Taufik Abdullah memberikan gambaran tentang keberagaman konflik antara hukum Islam dan adat, ada beberapa konflik internal diakui dan dijaga demi terjagannya sistem kemasyarakatan minangkabau secara keseluruhan, namun beberapa adat itu ditoleransi dan dilindungi bahkan dilembagakan, disamping itu masih ada sebagian yang meminimalkan konflik dengan

${ }^{7}$ Hamka, Ajahku: Riwayat Hidup Dr. H. Abd. Karim Amrullah dan perdjuangan Kaum Agama di Sumatera, (Djakarta, 1958). Hlm. 23-24.

${ }^{8}$ M. Nasrun, Dasar Falsafah Adat Minangkabau, (Bulan Bintang, Jakarta 1957), hlm. 3. 
Vol. 2 No. 2 Juli 2020

memperhatikan potensi terpecahbelahnya sistem kemasyarakatan secara keseluruhan, ada beberapa kasus dimana integrasi antara Islam dan adat mengikuti pola kesukuan setempat, tetapi ada juga kenyataan dimana hubungan antara Islam dan adat hanya bertujuan untuk memelihara agar konflik tidak terjadi.

\section{Teori Konstruksi Sosial L. Berger dan Thomas Luckman}

Istilah konstruksi sosial atas realitas (social construction of reality) didefinisikan sebagai proses sosial melalui tindakan dan interaksi dimana individu menciptakan secara terus-menerus suatu realitas yang dimiliki dan dialami bersama secara subyektif.

Berger dan Luckman mengatakan institusi masyarakat tercipta dan dipertahankan atau diubah melalui tindakan dan interaksi manusia. Meskipun masyarakat dan institusi sosial terlihat nyata secara obyektif, namun pada kenyataan semuanya dibangun dalam definisi subjektif melalui proses interaksi. Objektivitas baru bisa terjadi melalui penegasan berulang-ulang yang diberikan oleh orang lain yang memiliki definisi subyektif yang sama. Pada tingkat generalitas yang paling tinggi, manusia menciptakan dunia dalam makna simbolis yang universal, yaitu pandangan hidupnya yang menyeluruh, yang memberi legitimasi dan mengatur bentuk-bentuk sosial serta memberi makna pada berbagai bidang kehidupannya.

Proses konstruksinya, jika dilihat dari perspektif teori Berger \& Luckman berlangsung melalui interaksi sosial yang dialektis dari tiga bentuk realitas yang menjadi entry concept, yakni subjective reality, symbolic reality dan objective reality. Selain itu juga berlangsung dalam suatu proses dengan tiga momen simultan, eksternalisasi, objektivikasi dan internalisasi.

a. Objective reality, merupakan suatu kompleksitas definisi realitas (termasuk ideologi dan keyakinan) serta rutinitas tindakan dan tingkah laku yang telah mapan terpola, yang kesemuanya dihayati oleh individu secara umum sebagai fakta.

b. Symblolic reality, merupakan semua ekspresi simbolik dari apa yang dihayati sebagai "objective reality" misalnya teks produk industri media, seperti berita di media cetak atau elektronika, begitu pun yang ada di film-film.

c. Subjective reality, merupakan konstruksi definisi realitas yang dimiliki individu dan dikonstruksi melalui proses internalisasi. Realitas subjektif yang dimiliki masing-masing individu merupakan basis untuk melibatkan diri dalam proses eksternalisasi, atau proses interaksi sosial dengan individu lain dalam sebuah struktur sosial. Melalui proses eksternalisasi itulah individu secara kolektif berpotensi melakukan objectivikasi, memunculkan sebuah konstruksi objektive reality yang baru.

Melalui sentuhan Hegel yakni tesis-antitesis-sintesis, Berger menemukan konsep untuk menghubungkan antara yang subjektif dan objektif melalui konsep dialektika, yang dikenal dengan eksternalisasi-objektivasi-internalisasi.

1. Eksternalisasi ialah penyesuaian diri dengan dunia sosio-kultural sebagai produk manusia. "Society is a human product". 
Vol. 2 No. 2 Juli 2020

2. Objektivasi ialah interaksi sosial dalam dunia intersubjektif yang dilembagakan atau mengalami institusionalisasi. "Society is an objective reality".

3. Internalisasi ialah individu mengidentifikasi diri di tengah lembaga-lembaga sosial atau organisasi sosial di mana individu tersebut menjadi anggotanya. "Man is a social product"

C. Analisis

Analisis Pelaksanaan Waris Islam dan Pandangan Masyarakat Enggano

Pelaksanaan Hukum Waris Adat etnik Enggano dan Pandanganya tehadap Hukum Waris Islam

Selama ini banyak orang mengenal sistem kekerabatan matrilineal hanya terfokus pada suku adat minangkabau.Suku Enggano sebagai salah satu suku asli Bengkulu dengan ciri khas adat dan budayanya yang unik karena letak geografis yang cukup terisolasi yaitu berada di pulau Enggano, sebuah pulau terluar di barat sumatera bagian selatan menganut sistem matrilineal dengan perempuan sebagai pewaris suku.Hal ini dikarenakan dahulu sering terjadi peperangan antar suku di pulau Enggano serta budaya merantau meninggalkan kampung halaman bagi kaum laki-laki etnik Enggano, sehingga warisan yang biasanya berupa barang tidak bergerak seperti tanah diwariskan kepada anak perempuan.Sedangkan kaum lakilaki hanya menerima peralatan pertanian dan senjata tajam.Meskipun menganut sistem matrilineal, kepala suku tetaplah kaum laki-laki.

Terlalu seringnya peperangan dan kegiatan kaum lelaki yang sering merantau meninggalkan kampong halaman membentuk sistem kekerabatan matrilineal pada etnik Enggano yang menetapkan perempuan sebagai pewaris suku dan nama suku pun diwariskan dari nama suku ibu.

Meskipun garis matrilineal yang diterapkan, yang berhak menjadi kepala suku tetap laki-laki karena kerasnya kehidupan saat itu.Menurut sosiolog Universitas Bengkulu, Santoso.sistem matrilineal merupakan sistem yang banyak berkembang di Sekitar Sumatera, seperti pada suku Minang di Sumatera Barat dan suku Semendo di Kabupaten Pagar Alam, Sumatera Selatan.

"Sistem ini dianut karena banyak lelaki sering merantau sehingga potensi kehilangan properti suatu suku sangat besar. Kaum perempuan ditunjuk menjadi ahli waris dan penjaga hak waris suku karena pergerakan mereka relatif sempit banyak berdiam di kampung halaman",

Perubahan besar terjadi sekitar tahun 1866. Menurut Alfaret, perubahan ditandai dengan berakhirnya perang antarsuku dan banyak penduduk yang keluar dari Pulau Enggano untuk merantau ke Jawa dan Sumatera. Terjadi pengurangan jumlah penduduk yang cukup besar. ${ }^{10}$

"Wawancara dengan: Ramlan, (tokoh adat Enggano), 10 Mei 2014. 
Vol. 2 No. 2 Juli 2020

Saat ini, masyarakat suku Enggano sudah cukup berubah.Tidak sedikit dari mereka yang bermigrasi ke Pulau Jawa atau Sumatera. Namun masih banyak juga yang tetap menjaga nilai-nilai dan norma sosial masyarakat setempat. Peperangan pun sudah tidak terjadi seiring dengan cara musyawarah yang kerap dilakukan setiap adanya konflik.

Perlu ditegaskan kembali bahwa harta waris yang diserahkan kepada pihak perempuan dalam pelaksanaan waris etnik Enggano tidaklah kepemilikan secara mutlak dimiliki oleh seorang, akan tetapi tugasnya hanya menjaga dan mengelola sebagai aset keluarga. Pandangan Islam mengenai ini penulis mengkaitkan pembagian harta waris secara kolektif yang terjadi pada etnik Enggano dengan ayatayat al-Qur'ān yang menjelaskan tentang perintah untuk menjaga dan mengelola harta anak yatim.

Di sisi lain Pemahaman yang umum dari masyarakat Bengkulu berkaitan dengan hukum waris, bahwa sistem waris yang selama ini diyakini dan diterapkan ditengah-tengah masyarakat pada prinsipnya sudah melaksanakan nilai-nilai dasar yang sudah ditetapkan dalam hukum waris Islam. Hal mendasar yang menjadi acuan adalah prinsip keadilan dalam pembagian waris bagi ahli waris. Menurut mereka hal ini sudah sesuai dengan prinsip dasar hukum Islam, sebab membicarakanhukum Islam berartiberbicaraIslam itu sendiri, sebab memisahkan antara hukum Islam dengan Islam adalahsesuatuyangmustahil,selainhukum itubersumberdariagama Islam,hukum Islam jugatidakdapatdipisahkandariimandan

kesusilaan.SebabketigakomponenintiajaranIslam adalahiman, hukum, dan akhlak adalah suatu rangkaian kesatuan yang membentuk agama Islam itu sendiri.

Setelah mengkristal menjadi Islam dan diturunkan ke bumi makaIslam menjadirahmatanlilalaminyangmencakupseluruhaspek kehidupan, aspek kehidupan itu sendiri terdiri atas tiga bagian pokok yaituTuhan,manusia,danalam.Kumpulan ajaran-ajaran pokok Islam tersebutterangkum dalam dalam al-Qur'āndanhadistyangmembentuk sebuahajaran tentang Islamyanglazimdisebutaqidah.Akhirnya aqidah juga terbagi menjadi tiga bagian, aqidah tentang Tuhan, aqidah tentangmanusiadanaqidahtentang alam. pemahaman tentang aqidah tidak hanyadibatasi pada tauhid menyangkut Tuhan, Malaikat, Rasul, kitab,Takdirdanharikiamat,padahalakidahmenyangkuttotalitas masalah tentang ke-tuhanan, ke-alaman, dan kemanusiaan.

Dalam pandangan Islam,tujuanakhirhukumadalahkeadilan atau kemaslahatan. Kaitanya dengan hukum Islam, keadilan harus dicapai meski mengacu pada pokok agama Islam, yaitu al-Qur'ān dan Hadis. Arti dari tujuan keadilanmelaluijalurhukum yangharusberawaldariduasegidan mengarah pada keadilan dua segi juga. Khususnya yang berkaitan dengan hukum agar mampu tampil sesuai dengan prinsip keadilan secaraumum.Perpaduanmencarikeadilan menjadistandarhukum universal yang mampu tampil dimanapun dan kapanpun sesuai dengan fitrah diturunkanya Islamkemukabumi.

Maksud dari muara keadilan dua segi adalah tujuan akhir berupa keadilan 
Vol. 2 No. 2 Juli 2020

yang harus dicapai oleh sebuah sistem hukum universal mesti berorientasi pada keadilan terhadap manusia dan keadilan terhadap Tuhan. Keadilan bagi manusia mengarah pada berbagaidefinisikeadilanyang tidakbukanmungkinantarasatu masyarakatmanusiadengan yanglainya berbedadalammengartikan keadilan hukum. Artinya fleksibilitas produk keadilan mutlak perlu diperlakukandalam heterogenitasmanusiadanlingkunganya,

sedangkanmuarakeadilanadalahkepadaAllah.Hukum Allahadalah produkhukum yangtetapmenempatkan Allahsesuaidengan proporsinya sehingga perbuatan manusia harus tetap dalam koridor hukumAllah atau dengan istilah lain yaitu hak Allah dan hak hamba, menurut Muhammad Abu Zahrah dalam karyanya Usul alFiqh, beliau menjelaskan bahwa hak seseorang untuk mewarisi harta peninggalan ahli warisnya yang meninggal dunia termasuk ke dalam kategori kategori hak hamba atau hak perorangan secara murni. Beliau menyejajarkan hak untuk mewarisi dengan hak untuk menagih atau menerima piutang dan masalahmasalah lain yang berhubungan dengan pemilikan harta. Setelah menegaskan bahwa hak mewarisi adalah hak hamba secara murni, Abu Zahrah menjelaskan lebih lanjut bahwa: "melanggar hak hamba adalah sebuah kedzaliman. Allah tidak menerima taubat seseorang yang memakan hak hamba, kecuali jika yang bersangkutan membayar hak itu kepada kepada pemiliknya atau digugurkan oleh pemilik atau memaafkannya. Hak semacam ini tidak lain adalah untuk memelihara kemaslahatan perorangan.

Berdasarkan keterangan Abu Zahrah tersebut, pembagian harta warisan, bilamana setiap pihak ahli waris secara rela membaginya secara kekeluargaan dengan kesepakatan setiap pihak yang terkait. Bahkan berdasarkan hal tersebut, adalah sah bilamana ada diantara ahli waris yang merelakan atau menggugurkan haknya dalam pembagian harta warisan itu untuk diserahkan kepada ahli waris yang lain. Harta warisan boleh dibagi secara kekeluargaan, diakui pula oleh pasal 183 Kompilasi Hukum Islam.

Pendapat ini sejalan dengan ungkapan Freidmenn, bahwa selama standar prinsip keadilan tidak berpegang pada agamamaka pedomanitutidak akan mencapaiidealprinsipkeadilan.Padahal sebuahprinsipadalahstandaryang tidak akan berubah. Perubahan hanyapadatataranoperasionalsaja. Sedangkan prinsip yang utama tidak akan berubah. ${ }^{1}$

Mengacu kepada teori Maqashid as-Syari'ah Syatibi bahwa tujuan utama dari Hukum Islam adalah terwujudnya kemaslahatan (mashlahah). Adapun dasar konsep kemaslahatan, setidaknya dalam tradisi ulama, diklasifikasikan menjadi beberapa tingkatan seperti: ${ }^{12}$

1. Kemaslahatan dzaruriyat; yaitu sesuatu yang harus ada untuk tegaknya kehidupan manusia. Kebutuhan-kebutuhan ini yang bersifat esensial (primer) bagi kehidupan manusia. Kebutuhan esensial ini adalah memelihara agama, jiwa, akal, keturunan

${ }^{11}$ Friedman, Jonathan, Cultural Identity and Global Process.(London: Sage Publications, 2001), hal. 123.

${ }^{12}$ Syari'at diturunkan bagi umat manusia dalam rangka mewujudkan kemaslahatan (mashlahah) mereka, baik kemaslahatan di dunia maupun di akhirat. Lihat Asy-Syathibi, AlMuwafaqat fi Usul al-Ahkam (ttp.: Dar al-Rasyad al-Hadisah, t.t.), Jilid I, Juz I, hlm. 2 
Vol. 2 No. 2 Juli 2020

dan harta. Tidak terpenuhinya kebutuhan-kebutuhan itu akan mengakibatkan terancamnya eksistensi kelima hal pokok tersebut.

2. Kemaslahatan al-hajiyat; yaitu sesuatu yang dapat menghindarkan manusia dari kesulitan bagi subjek hukum. Kemaslahatan ini tidak termasuk kebutuhan yang esensial: jika kemaslahatan ini tidak terpenuhi, maka tidak akan menimbulkan kerusakan atau mengancam eksistensi manusia melainkan hanya akan menyebabkan kesulitan. Kelompok maslahat ini sangat erat kaitannya dengan keringanan (rukhsah) dalam fikih.

3. Kemaslahatan tahsiniyat; yaitu kemaslahatan yang menopang peningkatan martabat seseorang dalam masyarakat dan di hadapan Allah swt. Namun, meninggalkan kemaslahatan ini tidak akan mengancam eksistensi manusia atau menimbulkan kesulitan, karena ia hanya bersifat sebagai pelengkap kehidupan. ${ }^{13}$

Dalam kasus penggunaan hukum waris adat di Bengkulu dengan asas waris individual bilateral penulis berpendapat bahwa tidak ada pertentangan antara sistem hukum waris Islam dan hukum waris adat, keduanya sama-sama menganut sistem kewarisan individualbilateral artinya sejak terbukanya waris (meninggalnya pewaris) harta warisan dapat dibagi-bagi pemilikannya antara ahli waris dan tidak membedakan antara lelaki dan perempuan.Dalam pembagian waris masyarakat adat di Bengkulu dilakukan dengan mengadakan musyawarah di antara ahli waris untuk menentukan dan menetapkan bagian masing-masing ahli waris dilakukan dengan perdamaian dan berdasarkan rasa saling rela dan saling menerima sehingga terwujud kerukunan dan keutuhan keluarga serta supaya tidak ada yang merasa dirugikan. Hal demikian di atur juga dalam KHI pasal 183 yang berbunyi: "para ahli waris diperbolehkan bersepakat melakukan perdamaian dalam menentukan harta waris setelah masing-masing menyadari bagiannya". dalam farā'iḍ untuk menyelesaikan harta waris semacam ini disebut dengan takhārujatau tasāluhdimana para ahli waris melakukan musyawarah dalam pembagian harta waris diluar ketentuan syara'.

Pembagian harta waris di masyarakat adat Bengkulu yang dibagikan secara merata dan seimbang serta melalui proses musyawarah, hal tersebut mereka rasa cukup adil dan melegakan bagi masing-masing ahli waris sehingga hal tersebut sudah menyentuh tujuan dari syari'at Islam, yaitu kemaslahatan, lebih tepatnya kemaslahatan al-hajiyat; yaitu sesuatu yang dapat menghindarkan manusia dari kesulitan bagi subjek hukum (ahli waris). Apabila hukum kewarisan Islam dipaksakan untuk digunakan kepada mereka, sementara mereka belum siap untuk melaksanakannya, bukan tidak mungkin perselisihan, pertengkaran dan permusuhan yang akan terjadi. Dengan demikian maqashid as-syari'ah tidak tercapai, atau dalam kaedah fiqhiyah sering kita dengar dar'u al-mafashid muqodamu alaa jalbu mashalih (menghilangkan kerusakan itu lebih didahulukan dari memunculkan kemaslahatan). Hal ini sejalan pula dengan salah satu metode ijtihād yaitu al-Urf (adat atau kebiasaan yang baik), jumhur ulama memberikan ketentuan mengenai 'urf antara lain:

${ }^{13}$ Kemaslahatan makhluk dapat tercapai apabila lima hal primer dalam hidupnya telah terjamin. Lima hal tersebut antara lain agama (ad-din), jiwa (an-nafs), akal (al-'aql), keturunan (an-nasl), dan harta benda (al-mal). Ibid., hlm. 5 
Vol. 2 No. 2 Juli 2020

a. Tidak menyebabkan kemafsadatan dan menghilangkan kemaslahatan;

b. Tidak berlaku pada umumnya orang muslim;

c. Tidak berlaku pada ibadah mahdah;

d. 'Urf tersebut sudah memasyarakat ketika akan ditetapkan hukumnya;

\section{B. Pelaksanaan Hukum waris adat Engganodalam perspektif Teori Kesadaran Hukum}

Kesadaran hukum berkaitan dengan nilai-nilai yang tumbuh dan berkembang dalam suatu masyarakat. Dengan demikian masyarakat mentaati hukum bukan karena paksaan, melainkan karena hukum itu sesuai dengan nilainilai yang ada dalam masyarakat itu sendiri, sebagaimana pelaksanaan waris adat di Bengkulu bahwa mereka melaksanakan pembagian waris dengan kesadaran untuk mewujudkan kemashlahatan dengan cara mereka yaitu melalui musyawarah mufakat.

Pengertianhukum

Islamyangdemikianluasdengan berbagaihalyangterkaitdenganhukummenjadisingkatdalam ungkapan MacDonald, yangmenyebut hukumIslamadalah'TheScienceof allthings,humananddevine". PandanganMacDonaldtersebut merupakankristalisasidari sistem hukum yangmampumelihat pluralitassebagairealitasempiris.Pluralritasdisini bukanhanya manusiadalambentukhubungangarishorizontal,tetapipluralyang menyangkut hubungan horizontal dan vertikal.

Berbeda dengan prinsip keadilan perspektif agama, dalam perspektif hukum adat, bahwa keadilan merupakan kristalisasi nilai-nilai yang dipengaruhi oleh lingkungan dan alam sekitar yang bersifat magis-religius ${ }^{14}$. Alam pikiranyangmempertautkanantarayangnyatadenganyangtidaknyata. Antaraalam fanadenganalam baka,antarakekuatanmanusiadengan kekuatan tuhan antara hukum manusia dengan hukum Tuhan.

Pada umumnya masyarakat hukum adat sangat sukar berfikir secara rasional tetapi lebih dipengaruhi oleh pola pikir yang komunal magisreligius.Alam pikiraninimenempatkankehidupan manusia merupakan bagian yang tidak dapat terpisahkan dari alam. Kehidupanmanusiatautmenautdengankeadaanalam apabilaalam mengalami kegoncangan berarti menusia melakukan perbuatan yang melanggar ketentuan hukum alam. Terjadinya bencana bencana merupakanulahdariperbuatanmanusiayangtidakmematuhihukum telah ditetapkanTuhankepada manusia,sehinggamanusiamenerimalaknat dari Tuhan. Baik buruknya keadan alam ditentukan oleh perbuatan manusia itu sendiri.

Hukum adat sebagaimana dikemukakan oleh Holleman, ${ }^{15}$ hukum adat mempunyai empat ciri umum yang dipandang sebagai dari satu kesatuan yang tidak dapat dipisahkan.Adapun empat ciri tersebut adalah pertama religius magis

\footnotetext{
${ }^{14}$ Sarjono Soekanto, Hukum Adat Indonesia, hal. 53

${ }^{15}$ Hoffman, Diane M. 1990. Beyond Conflict: Culture, Self, and Intercultural Learning Among Iranians in USA. New York: JIR.), hal. 20-21
} 
Fakultas Hukum Universitas Komputer Indonesia

Vol. 2 No. 2 Juli 2020

yaitu perpaduan pikiran yang mengandung logikaanimismeyaitupandanganyangberhubungandenganalam gaib. Kedua adalah Komun yaitu sifat yang mementingkan kepentingan bersama daripada kepentingan pribadi. Sifat yang ketiga adalah Tunai yaitu kebiasaandalam masyarakatdalam jualbelibersifattunaiyaituhakdan kewajibandilakukandalam waktuyangsama. Yangkeempatadalah kongkrit yaitu dalam melakukan perbuatan harus bersifat nyata.

\section{KESIMPULAN}

\section{A. Kesimpulan}

Berdasarkan pembahasan hasil penelitian lapangan dan juga telaah teortis, maka dapat disimpulakn bahwa hukum waris Islam dalam Pandangan dan Pelaksanaan masyarakat Rejang dan Serawai dapat diuraikan sebagai berikut:

1. Masyarakat Enggano telah menempatkan hukum adat waris sebagai sesuatu yang utama. Hukum waris Islam hanya dipahami secara substantif, bahwa terdapat nilai-nilai dalam agama Islam yang sudah diadopsi dan mewarnai sistem hukum adat yang mereka terapkan di masyarakat selama ini. Rendahnya pengetahuan dan pemahaman masyarakat tentang hukum waris Islam ini disebabkan karena kurangnya sosailsisai dari para alim ulama dan pastinya pemerintah sebagai pemegang regulasi pemerintahan yang memiliki kekuasaan dan pendanaan untuk melaksanakan sosialisasi ini, baik melalui majlis-majlis taklim maupun melalui kajian rutin secara kontinyu. Ada kecenderungan keengganan masyarakat menerapkan hukum waris Islam karena menganggap bahwa hukum waris Islam terlalu banyak aturan yang pada akhirnya menjauhkan dari rasa keadilan dalam proses pembagian waris. Keadilan yang dipahami oleh masyarakat adalah keadilan yang mendasarkan atas keadilan progresif dalam pelaksanaan waris adat mereka.

2. Masyarakat Enggano menempatkan hukum waris Islam dalam berbagai dimensi, berdasarkan pemahamannya terhadap pewarisan yang sebatas menggunakan prinsip keadilan menurut perspektif adat. Oleh karena itu, hukum waris Islam ditempatkan dalam dua dimensi, yaitu: pertama, menempatkan hukum waris Islam sebagai sebuah tata aturan yang berisi nilai-nilai agama, yang bagi masyarakat Enggano nilai-nilai tersebut sudah diterapkan dalam hukum waris adatnya. Kedua, hukum waris Islam ditempatkan seperti halnya hukum adat. Pemahaman masyarakat Enggano bahwa apa yang diyakini sebagai hukum waris adat yang sudah mengadopsi hukum waris Islam pada akhirnya menempatkan pemahamanya pada dimensi yang ambigu. Satu sisi mereka menganggap bahwa hukum waris yang diterapkanya sebagai sebuah tata aturan yang sudah relavan dan tidak bertentangan dengan hukum waris Islam. Sementara disisi yang lain, implementasi dari hukum waris adat tersebut masih jauh dari prinsip dasar hukum waris Islam.Bagi para peneliti ataupun ilmuan, untuk menindaklanjuti terhadap fenomena penafsiran ayat-ayat al-Qur'ān tentang waris yang terjadi pada masyarakat adat Serawai, mungkin hasil penelitian Disertasi ini bisa dijadikan pijakan awal terhadap berbagai perseteruan yang terjadi antara pelaksanaan waris adat di berbagai daerah dengan berdasarkan semangat mereka (masyarakat adat) dalam usaha untuk mengamalkan hukum waris Islam walaupun tidak secara 
Vol. 2 No. 2 Juli 2020

kaffah, akan tetapi nilai kemaslahatan yang didapat yaitu sesuai dengan tujuan hukum Islam (maqāshid asy-Syari'ah).

3. Dalam perspektif teori konstruksi sosial, bahwa pemahaman dan kebutuhan masyarakat Enggano terhadap hukum waris Islam merupakan bentuk dari kristalisasi nilai-nilai yang mereka yakini sebagai sebuah tata aturan yang merupakan konstruksi dari kebiasaan dan adat budaya masyarakat bengkulu. Sehingga pada akhirnya konstruksi ini merupakan perpaduan antara nilai-nilai lama yang sudah ada (adat) dengan nilai-nilai agama yang dianutnya (nilai Islam). Meskipun nilai baru yang lahir bukan merupakan bentuk asimilasi, tetapi bentuk dari akulturasi.

\section{Daftar Pustaka}

Abdullah, Taufiq (editor), Islam dan Perubahan Sosial, Jakarta : Bharatara, 1973. dan Sharon Shiddieque (editor), Tradisi dan Kebangkitan Islam di Asia

Tenggara, Jakarta : LP3ES, 1988.

Agama dan Perubahan Sosial, Jakarta : Rajawali, 1971.

,Adat and Islam, an Examination of Conflict In Minangkabau, Southest

Asia Program Publications at Cornell University

, Islam, History and Sosial Change in Minangkabau. Dalam Lyan L.

Thomas \& Frans Von Benda-Beckman (edt), Continuity and Change in Minangkabau, Ohio: Center for Southeast Asian Studies, 1985

Afandi, Ali. Hukum Waris, Hukum Keluarga, Hukum Pembuktian Menurut BW. Jakarta : Bina Aksara, 1983.

Ali, Chidir. Yurisprudensi Hukum Perdata Islam di Indonesia, Bandung : AlMaarif, 1979.

Ali, Muhammad Daud dan Habibah Daud, Lembaga-lembaga Islam di Indonesia, Jakarta : Raja Grafindo Persada, 1985.

Hukum Islam dan Peradilan Agama, Jakarta : Raja Grafindo Persada, 1997.

Hukum Islam : Pengantar Ilmu Hukum dan Tata Hukum

Islamdi Indonesia, Jakarta : Raja Grafindo Persada, 2000.

Ali, Zainuddin, Sosiologi Hukum, Cet-6, Jakarta: Sinar Grafika, 2006.

Anshori, Abdul Ghofur, Hukum Kewarisan Islam di Indonesia : Eksistensi dan Adaptabilitas, Yogyakarta: UGM Press, 2012.

Azhari, Muhammad Tahir, Negara Hukum : Suatu Studi tentang Prinsipprinsipnya dilihat dari Segi Hukum Islam, Implementasinya pada Periode NegaraMadinah dan Masa Kini, Jakarta : Bulan Bintang, 1992.

Azra, Azyumardi (Penyunting). Persfektif Islam di Asia Tenggara, Jakarta : Yayasan Obor Indonesia, 1989.

Azra, Azyumardi, Renaisans Islam Asia Tenggara : Sejarah Wacana dan Kekuasaan, Bandung : Remaja Rosdakarya, 1999.

Bogdan, Robert C. \& Baiklen. Qualitative Research for Education : An Introduction to Theory and Methods. Boston: Allyn and Bacon Inc. 1982. 
Vol. 2 No. 2 Juli 2020

.. Introduction To Qualitative Research Methods.

Terjemahan Arief Furchan. Surabaya: Usaha Nasional. 1992

Daud, Habibah, Pilihan Lembaga Peradilan Dalam Menyelasaikan Masalah Kewarisan Orang-orang Islam di Jakarta, Jakarta : PLPIS, 1977.

Daud Ali, Muhammad, Hukum Islam dan Peradilan Agama, Jakarta: Raja Grafindo Persada, 1997.

Departemen Agama RI, Kenang-kenangan Seabad Peradilan Agama di Indonesia, Jakarta : Departemen Agama RI, 1985.

, Himpunan Fatwa Peradilan Agama di Jawa, Madura,

Sebagian Kalimantan Selatan dan Timur, Jakarta : Departemen Agama RI, 1983/1984.

1990.

Al-Qur'an danTerjemahnya, Jakarta: Depag RI, cet. 5,

Efendi, Satria, M. Zein, Problematika Hukum Keluarga Islam Kontemporer, Jakarta: Kencana, 2010.

Faisal, Sanafiah. Penelitian Kualitatif: Dasar-Dasar dan Aplikasi. Malang: Yayasan Asah-Asih-Asuh. 1990.

Fathurrahman, Ilmu Waris, Bandung : Al-Ma'arif, 1981.

Habiburrahman, Rekonstruksi Hukum Kewarisan Islam di Indonesia, Jakarta: Kencana, 2011.

Hajar, M. Perkembagan Hukum Islam di Indonesia (Studi atas Keberadaan Hukum Kewarisan,) Yogyakarta : UII, 2002, tesis tidak diterbitkan.

Hanafi, A, Teologi Islam, Jakarta: Pustaka Al-Husna, 1987

Hazairin, Hukum Islam dan Masyarakat, Jakarta : Bulan Bintang, 1981.

, Hukum Kewarisan Bilateral menurut Al-Qur'an dan Hadist, Jakarta :

Tintamas, 1982.

, Hukum Kekeluargaan Nasional, Jakarta : Tintamas, 1963.

, Tujuh Serangkai Tentang Hukum, Jakarta : Bina Aksara, 1981.

Hamka. Studi Islam : Aqidah, Syari'ah dan Ibadah, Jakarta : Yayasan Nurul Islam, 1976.

,Islam dan Adat Minangkabau, Pustaka Panjimas, Jakarta,1985

Hoffman, Diane M. Beyond Conflict: Culture, Self, and Intercultural Learning

Among Iranians in USA. New York: JIR. 1990.

Ichtiyanto, Perkembangan Teori Berlakunya Hukum Islam di Indonesia, Bandung: Rosdakarya, 1991.

Idris, Taufik, Aliran-aliran Populer dalam Teologi Islam, Surabaya: Bina Ilmu, 1980.

Kusumuatmadja, Mochtar, Pembinaan Hukum dalam Rangka Pembangunan Nasional cet-1. Bandung : LPHK Fakultas Hukum Unpad-Bina Cipta, 1975.

Fungsi dan Perkembangan Hukum dalam

Pembangunan Nasional, Bandung : LPHK Fakultas Hukum Unpad-Bina

Cipta, 1976. 
Vol. 2 No. 2 Juli 2020

\section{Hukum, Masyarakat dan Pembinaan Hukum}

Nasional, Bandung : LPHK Fakultas Hukum Unpad-Bina Cipta, 1976.

Khalid Mas'ud, Muhammad, Filsafat Hukum Islam, Bandung: Pustaka, 1996

Muhammad, Bushar, Asas-asas Hukum Adat Suatu Pengantar, Jakarta : Pradnya Paramita, 1981.

Mulyono, Agus. Kehidupan Sosial Pendatang Asal Minang di Bengkulu. Bengkulu: Lembaga Penelitian Unib. 1992.

Nasrun, M, Dasar Falsafah Adat Minangkabau, Bulan Bintang, Jakarta 1957.

Nasution S. Metode Penelitian Naturalistik-Kualitatif. Bandung: Tarsito. 1996.

Nasution, Khoiruddin, Pengantar dan Pemikiran Hukum Keluarga (Perdata)

Islam Indonesia, Yogyakarta : Academia Tazzafa, 2010.

Nashiruddin, Muhammad. Kedudukan Sunnah dalam Islam, Yogyakarta : PP Muhammadiyah, 1985.

Lincoln, Y.S., \& Guba, E.G. 1985. Naturalistic Inquiry. Baverlay Hill: Sage Publications

Prodjodikoro, Wirjono, Hukum Warisan di Indonesia, Bandung : PT Bale, 1986. Diktat Hukum Waris Adat, Bengkulu : Fakultas Hukum Universitas Bengkulu , 1987.

, Diktat Hukum Waris Perdata, Bengkulu : Fakultas Hukum Universitas Bengkulu, 1987.

, Diktat Referensi Mata Kuliah Hukum Nasional,

Bengkulu : Fakultas Hukum, 1987.

Quraish Shihab, M. Tafsir Al-Misbhah : Pesan, Kesan dan Kerasian Al-Qur'an, Jakarta : Lentera Hati, 2000.

Ramulya, Idris, Hukum Kewarisan Islam, Jakarta : Ind-Hill-Co, 1984.

Rasyid, Sulaiman. Fiqh Islam, Jakarta : Attahiriyah, 1976.

Ramadlan, Said. Hukum Islam Ruang Lingkup dan Kandungannnya, Jakarta : Gaya Media Pertama, 1986.

Rist dalam Goetz J.P. \& Le Compte M.D. 1984. Etnography \& Qualitative Design in Educational Research. San Diego: Academic Press

Salman, Otje, Kesadaran Hukum Masyarakat terhadap Hukum Waris, cet. Ke-2, Bandung: PT. Alumni, 2007.

Siddik, Abdullah. Asas-asas Hukum Islam, Jakarta : Wijaya, 1980.

, Hukum Waris Islam dan Perkembangannya di Seluruh Dunia Islam, Jakarta : Wijaya, 1980.

Siddik, Haji Abdullah. Hukum Adat Rejang. Jakarta: Balai Pustaka. 1980.

Susiyanto, Perubahan Identitas Etnik dalam Kerangka Etnisitas (Studi Tentang Interaksi Antar Etnik dalam Masyarakat Multietnik di Kota Bengkulu), Bandung : Unpad. Disertasi, 2005. Tidak diterbitkan

Soekanto, Soerjono Hukum Adat di Indonesia, Jakarta: Rajawali, 1981. , Kedudukan dan Peranan Hukum Adat di Indonesia, Jakarta : Kurnia Esa, 1982.

Soerjono Soekanto dan Soleman B. Taneko, Hukum Adat Indonesia Jakarta : Rajawali Press, 1983. 
Vol. 2 No. 2 Juli 2020

Soerjono Soekanto dan Mustafa Abdullah, Sosiologi Hukum dalam Masyarakat Jakarta : Rajawali Press, 1982.

Soepomo, Bab-bab Hukum Adat, Jakarta : Pradnya Paramita, 1983.

Suminto, Aqib, Politik Islam Hindia Belanda, Jakarta : LPES, 1985.

Suparman, Eman, Hukum Waris Indonesia : Dalam Perspektif Islam, Adat dan BW Cet-2, Bandung: PT. Refika Aditama, 2007.

Thalib, Sayuti, Hukum Kewarisan Islam di Indonesia, Jakarta : Bina Aksara, 1984.

Recentio A Contratio: Hubungan Hukum Adat dengan Hukum Islam, Jakarta : Bina Aksara, 1985.

Wignjosoebroto, Soetandyo, Dari Hukum Kolonial Ke Hukum Nasional: Suatu Kajian Tentang Dinamika Sosial Politik dalam Perkembangan Hukum Selama Satu Selengah Abad di Indanesia, Jakarta: Raja Grafindo Persada.

Yahya, Mukhtar, Dasar-dasar Pembinaan Hukum Islam, Bandung : Al-Ma'arif, 1983.

Yusuf Musa, Muhammad, Islam : Suatu Kajian Komprehensif,. Terj. A. Malik Madany dan Hamim Ilyas. Jakarta: Rajawali, 1988.

Zainuddin, Ali, Pelaksanaan Hukum Waris di Indonesia, Jakarta : Sinar Grafika, 2008

Jurnal Ilmiah :

Jurisdictie, Jurnal Hukum dan Syariah, Volume 3, Nomor 1, Juni 2012.

Al-Manahij, Jurnal Kajian Hukum Islam, Vol. VIII. No. 1 2013, STAIB Purwokerto

Jurnal Ilmu Hukum, Vol. 2 No. 02 Februari 2012, Universitas Riau

Jurnal Inkoma, Tahun 16, Nomor 2, Juni 2005

Istiqro', Vol. VI/No.02/2003. Perta. Jurnal Inovarsi Pendidikan Tinggi Agama Islam

Jurnal Mimbar Hukum, Nomor 14 tahun 1994. 